\title{
Biomass gasification cogeneration - A review of state of the art technology and near future perspectives
}

\author{
Ahrenfeldt, Jesper; Thomsen, Tobias; Henriksen, Ulrik Birk; Clausen, Lasse Røngaard
}

Published in:

Applied Thermal Engineering

Link to article, DOI:

10.1016/j.applthermaleng.2011.12.040

Publication date:

2013

Document Version

Peer reviewed version

Link back to DTU Orbit

Citation (APA):

Ahrenfeldt, J., Thomsen, T., Henriksen, U. B., \& Clausen, L. R. (2013). Biomass gasification cogeneration - A review of state of the art technology and near future perspectives. Applied Thermal Engineering, 50(2), 14071417. https://doi.org/10.1016/j.applthermaleng.2011.12.040

\section{General rights}

Copyright and moral rights for the publications made accessible in the public portal are retained by the authors and/or other copyright owners and it is a condition of accessing publications that users recognise and abide by the legal requirements associated with these rights.

- Users may download and print one copy of any publication from the public portal for the purpose of private study or research.

- You may not further distribute the material or use it for any profit-making activity or commercial gain

- You may freely distribute the URL identifying the publication in the public portal 


\title{
Biomass gasification cogeneration - a review of state of the art technology and near future perspectives
}

\author{
Jesper Ahrenfeldt, Tobias P. Thomsen, Ulrik Henriksen, Lasse R. Clausen \\ Biomass Gasification Group, National Laboratory for Sustainable Energy - Ris $\varnothing$ DTU \\ Frederiksborgvej 399, 4000 Roskilde, Denmark
}

\begin{abstract}
Biomass is a renewable resource from which a broad variety of commodities can be produced. However, the resource is scarce and must be used with care to avoid depleting future stock possibilities. Flexibility and efficiency in production are key characteristics for biomass conversion technologies in future energy systems. Thermal gasification of biomass is proved throughout this article to be both highly flexible and efficient if used optimally. Cogeneration processes with production of heat-and-power, heat-power-and-fuel or heat-power-and-fertilizer are described and compared. The following gasification platforms are included in the assessment: The Harboøre up draft gasifier with gas engine, the Güssing FICFB gasifier with gas engine or PDU, the LT-CFB gasifier with steam cycle and nutrient recycling and finally the TwoStage down draft gasifier with gas engine, micro gas turbine (MGT), SOFC, SOFC/MGT or catalytic fuel synthesis.
\end{abstract}

\section{Keywords}

Gasification of biomass, co-generation, CHP, bio-fuels, SOFC, bio-MeOH, bio-SNG, fertilizer, Harboøre gasifier, Güssing gasifier, Viking gasifier, LT-CFB (Pyroneer)

\section{Introduction}

The transition from energy systems based on fossil fuels to energy systems based on renewable and sustainable fuels, is a transition from a stock based system to a flow based system. The flow based energy resources are to a large extent incompatible with the current energy infrastructure and a new and more complex structure is required. Meeting future demand for electricity, heat, cooling, fuels and materials with highly limited and fluctuating resources will require carefully planned allocation of the available resources and a highly flexible system. One of the few renewable resources that is capable of supplying all of the before mentioned commodities is biomass. However, biomass resources are scarce and will deplete rapidly if subjected to overexploitation, and it is therefore very important to use these resources efficiently and with care. Gasification of biomass has proved itself a highly efficient way to utilize biomass for a series of different purposes in processes with one or several useful outputs that is applicable on small or medium scale. The combination of flexibility and efficiency in biomass conversion has attracted increasing attention to the gasification technology platform in recent years. This work presents a review of the most stabile state-of-the-art gasification technologies, and describes some of the possibilities that cogeneration through gasification of biomass can provide in the emerging energy systems of tomorrow.

\section{State-of-the-art biomass gasification technology for cogeneration of heat and power}

Biomass gasification for combined heat and power production (CHP) is a promising technology which, especially in small-scale plants with an electric power output less than 10 MW, provides an attractive alternative to biomass combustion. The combination of biomass

Jesper Ahrenfeldt: jeah@ @isoe.dtu.dk, +45 21325344 
gasification and a gas engine for CHP is a logical choice in the small-scale range and with a biomass to power efficiency potential of $35-40 \%$, which is high compared to conventional technology, these plants can be very competitive. The emerging technology of gasification makes it possible to build decentralised biomass CHP plants in a scale that has not been sufficiently efficient before. The prospect of decentralised CHP utilisation of biomass with high efficiency is appealing in a country like Denmark where district heating is widespread. It is not only applicable for the construction of new plants, there is also huge potential for converting existing heating plants fuelled by biomass and gas engine CHP plants fuelled by natural gas. Figure 1 depicts a map of all heating- and power plants in Denmark in 2004. It shows a substantial number of biomass fired heating plants and decentralised CHP plants fuelled by natural gas. Almost all of the decentralised CHP plants fuelled by natural gas are gas engine based. Data from 2009 shows that more than 15 PJ of biomass and 8 PJ of natural gas was utilised in heating plants, and $30 \mathrm{PJ}$ of natural gas and $18 \mathrm{PJ}$ of biomass was utilised in decentralised CHP plants [1].

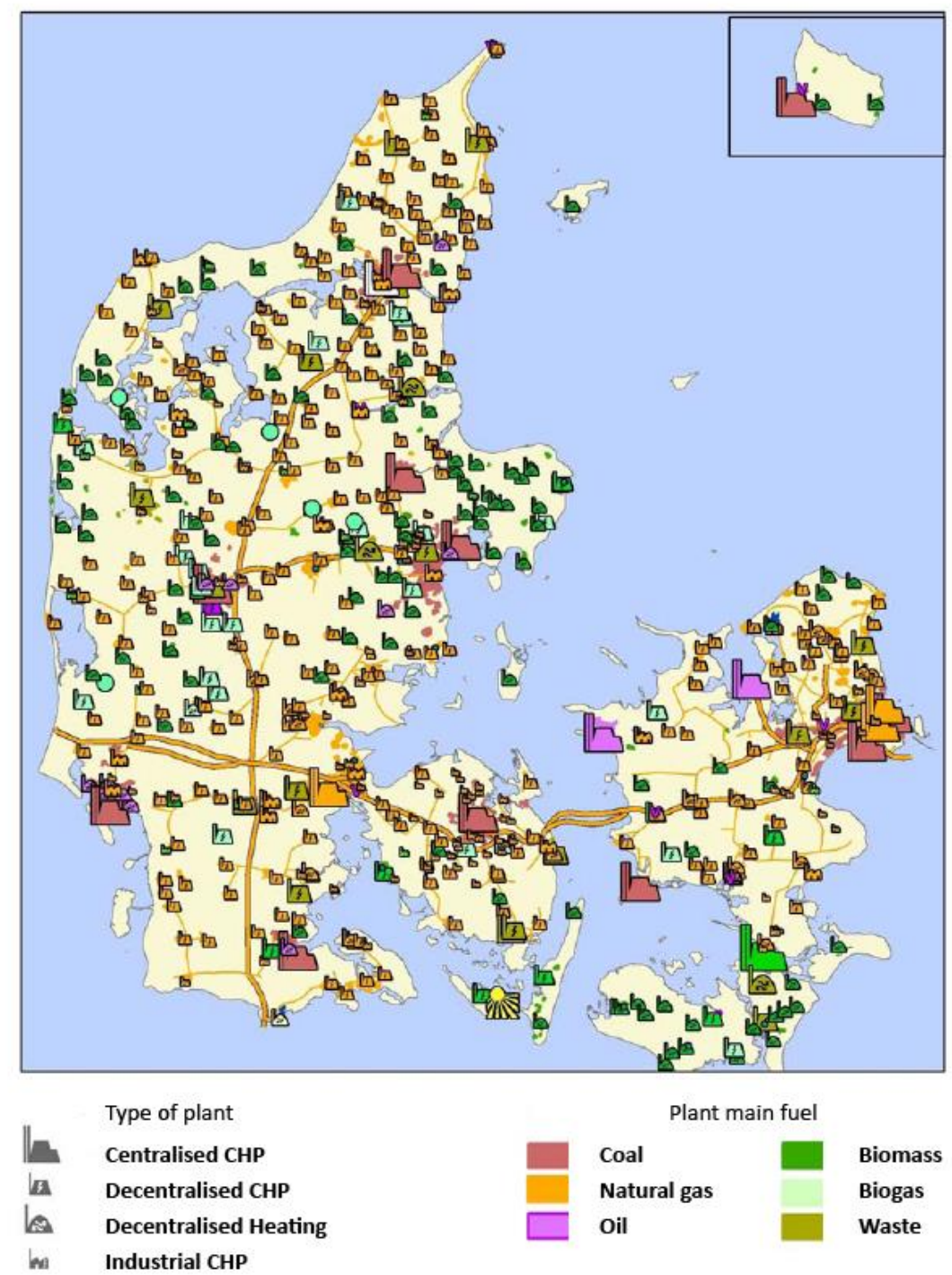

Figure 1: Denmark Energy Map 2004 - CHP and heating stations [2]

The high power efficiency of small scale biomass gasification CHP based on gas engines provides an opportunity for converting biomass fired heating plants into efficient CHP plants that has not previously been present. An advantage of such a conversion is that infrastructure and buildings already are at hand. Natural gas fuelled gas engine CHP plants can either be 
converted into pure biomass based plants or dual fuel plants, operating on either producer gas or natural gas or mixtures of both. The main advantage of a conversion of such plants is that the gas engine is already at hand and this is normally a major part of the total investment.

2.1 Stabile long term CHP operation with updraft gasifier and Fast Internal Circulating Fluid Bed (FICFB) gasifier

Proving a stabile long term operation is essential for upcoming technologies and especially in energy production as production halts in CHP plants can lead to shortages in heat supply and increased electricity prices - or even brownouts. Two of the most well proven and widely acknowledged gasifiers for CHP production from biomass are an updraft gasifier in Harboøre, Denmark and an FICFB gasifier in Güssing, Austria.

The CHP plant in Harboøre is an air-blown updraft gasifier (5200 kWth) that converts wood chips into producer gas with a lower heating value of approximately $6 \mathrm{MJ} / \mathrm{Nm}^{3}$ (dry basis, tarfree) [3]. The plant is designed for unattended operation. After gas conditioning, the product gas is used as fuel in two gas engines with generators producing electricity and heat for the grid. The main data of the plant is given in Table 1 .

Table 1: Data from the Harboøre plant [3]

\begin{tabular}{|r|l|}
\hline Gasification concepts & Up draft \\
\hline Thermal input [MW] & 5.2 \\
\hline Feedstock [-] & Wood chips \\
\hline Electric output (2 engines) [kW] & 1400 \\
\hline Thermal output [kW] & 3400 \\
\hline Overall electric efficiency [\%] & 28 \\
\hline
\end{tabular}

The plant is located at the municipality of Harboøre on the northwest coast of Jutland, Denmark. The plant was designed by Babcock \& Wilcox Vølund. Figure 2 below shows a process flow sheet of the Harbøre plant.

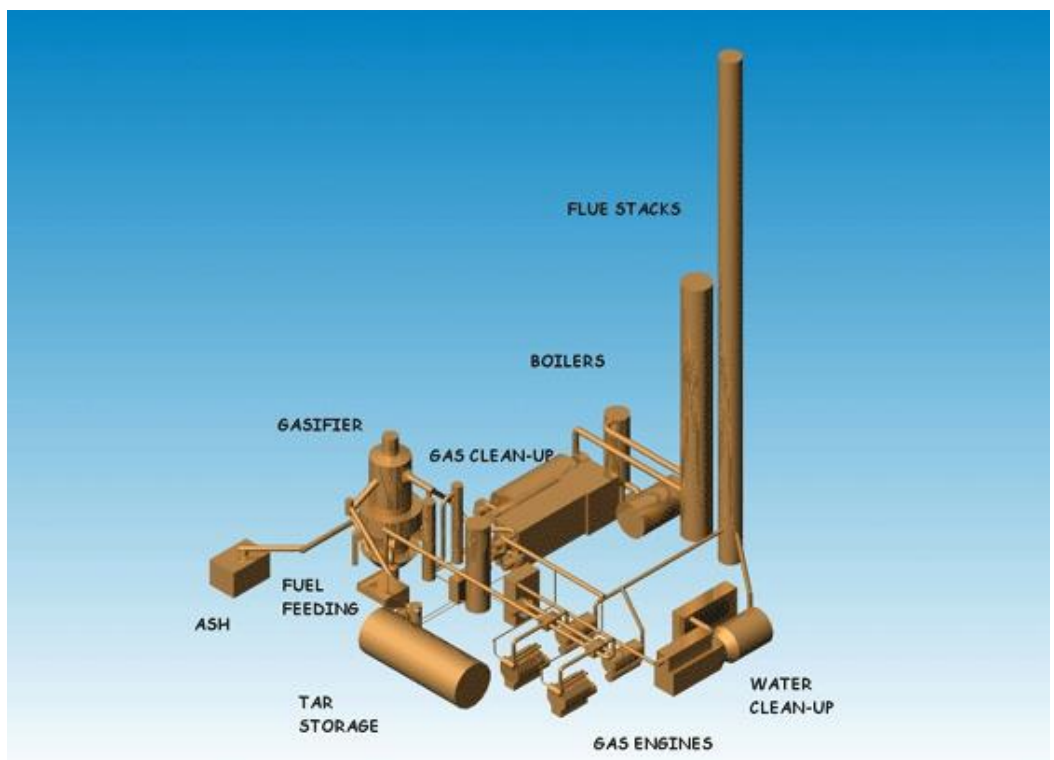

Figure 2: A process flow sheet for the CHP plant in Harboøre [3].

The raw product gas exits the gasifier at a temperature of about $75^{\circ} \mathrm{C}$. It contains about 80 $\mathrm{g} / \mathrm{Nm}^{3}$ of various tars and acids as well as a small amount of particles. At the first step of the gas conditioning system, the raw product gas is cooled down to a temperature of about $45^{\circ} \mathrm{C}$ supplying heat for the local district heat grid. The cooling results in condensation of a considerable amount of water and tar. In the following step, the majority of the remaining tar 
components in the product gas are removed in a wet electrostatic precipitator. After this, the amounts of tars and dust are each below $25 \mathrm{mg} / \mathrm{Nm}^{3}$. The product gas is fed to the engines by a booster-fan, which ensures a suitable pressure of the product gas.

In May 2010 the gasifier in Harboøre had a power production around $500 \mathrm{MWh}$ per month, and a total historical supply to the grid of more than $32.000 \mathrm{MWh}$. Operational experience covers 110.000 hours of gasifier operation and 70.000 hours of engine operation [4].

The CHP plant at Güssing in Austria is a FICFB (Fast Internal Circulating Fluidised Bed) steam gasifier that converts wood chips to a product gas with a heating value of approximately $12 \mathrm{MJ} / \mathrm{Nm}^{3}$ (dry basis). After the gas conditioning at the plant (a two-stage gas cleaning system), the product gas is used as fuel in a gas engine with a generator producing electricity and heat for the grid. If the engine is not in operation, the product gas can be burned in a boiler producing only heat. The main data of the plant is given in Table 2 below.

Table 2: Data from the Güssing plant $[5,6]$

\begin{tabular}{|r|l|}
\hline Gasification concepts & Fast internally circulating fluidised bed (FICFB) \\
\hline Thermal input [MW] & 8 \\
\hline Feedstock [-] & Wood chips \\
\hline Electric output [MW] & 2.0 \\
\hline Thermal output [MW] & 4.5 \\
\hline Overall electric efficiency [\%] & 25 \\
\hline
\end{tabular}

The plant was built between September 2000 and October 2001. Figure 3 below shows a process flow sheet of the CHP plant in Güssing.

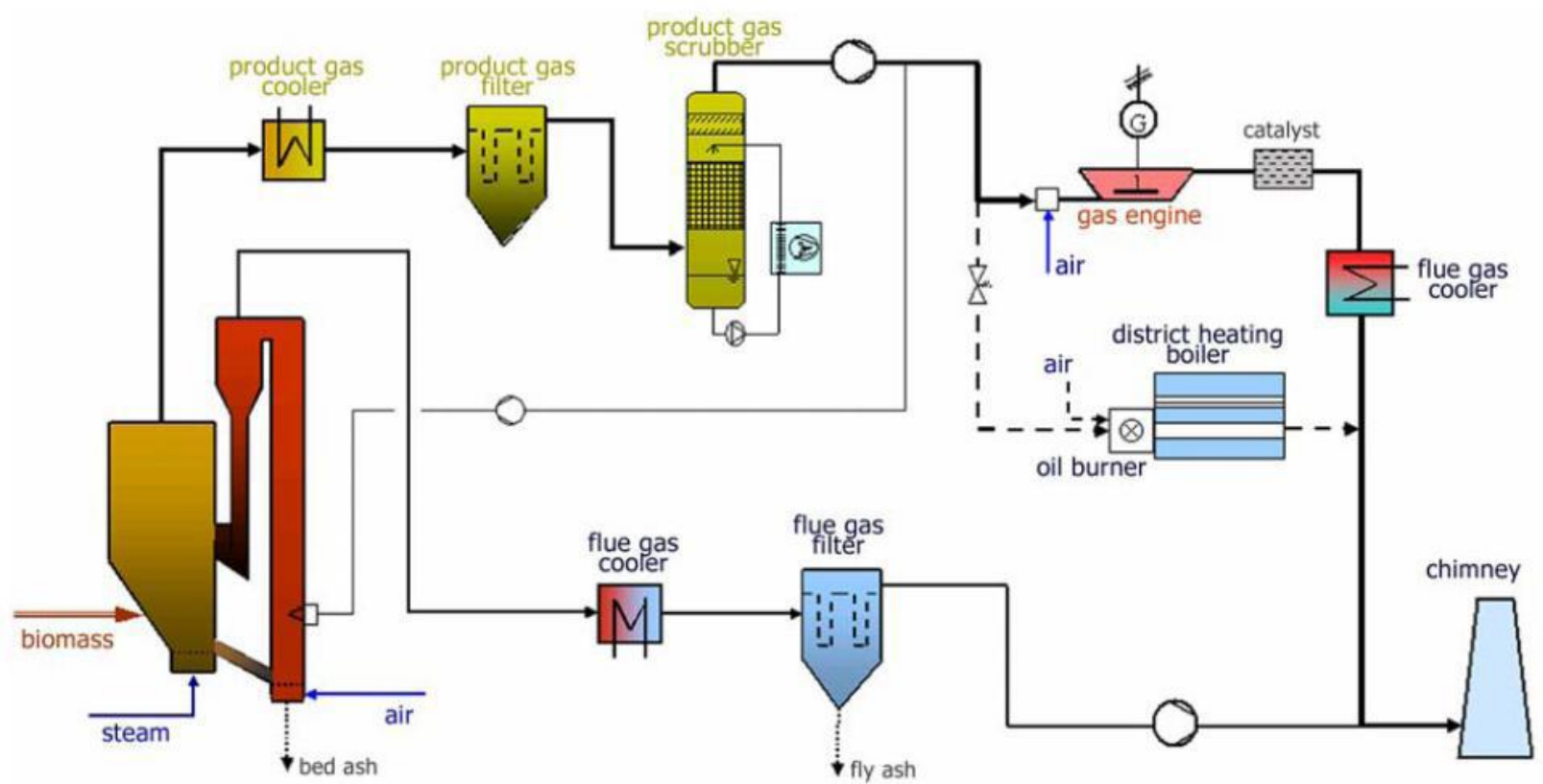

Figure 3: Process flow sheet for the CHP-Plant at Güssing [5]

The FICFB gasifier consists of two zones; a gasification zone and a combustion zone. The combustion zone provides heat through the bed material to the gasification zone. Steam is used as gasification agent in the gasification zone. This should in itself lead to a lower tar content compared to air blown gasifiers [5]. Olivine sand is used as bed material. The amount of tar in the raw product gas from the gasifier is about $1500-4500 \mathrm{mg} / \mathrm{Nm}^{3}$ (dry gas). Leaving the 
gasifier, the product gas is cooled down to a temperature of about $160-180{ }^{\circ} \mathrm{C}$. The product gas is passed through a fabric filter, removing the particles and some of the tar. The fabric filter is coated with material that is released when the filter is back-flushed. The released material consists of particles and some amounts of tar and is led back to the combustion zone of the gasifier. After this step, the product gas is led to a scrubber using 'oil' (RME) as scrubber liquid. Spent scrubber liquid saturated with tar and condensate is vaporized and led to the gasifier in the combustion zone. The amount of tar exiting the fabric filter is about $750 \mathrm{mg} / \mathrm{Nm}^{3}$ dry gas. Leaving the scrubber, the clean product gas has a very low tar content of about 10-40 $\mathrm{mg} / \mathrm{Nm}^{3}$ dry gas. The exhaust gas of the engine is catalytically oxidised to reduce $\mathrm{CO}$ emissions. In January 2009, the plant had operated for more than 40.000 hours since 2002 [7].

\subsection{Flexible CHP operation with TwoStage down draft gasifier}

At the Technical University of Denmark (DTU) the Biomass Gasification Group (BGG) has been working with research and development of staged gasification in fixed beds since 1989 . During this period different designs have been investigated [8]. The TwoStage process is characterized by having pyrolysis and gasification in separate reactors with an intermediate high temperature tar cracking zone [9]. This allows control of the process temperatures resulting in extremely low tar concentrations in the produced gas [10]. The gasification plant named "Viking" (see Figure 4) is a small-scale plant with a nominal thermal input of $70 \mathrm{~kW}$. The plant is fuelled by wood chips and is operating fully automated and unmanned, feeding the produced gas to a gas engine.

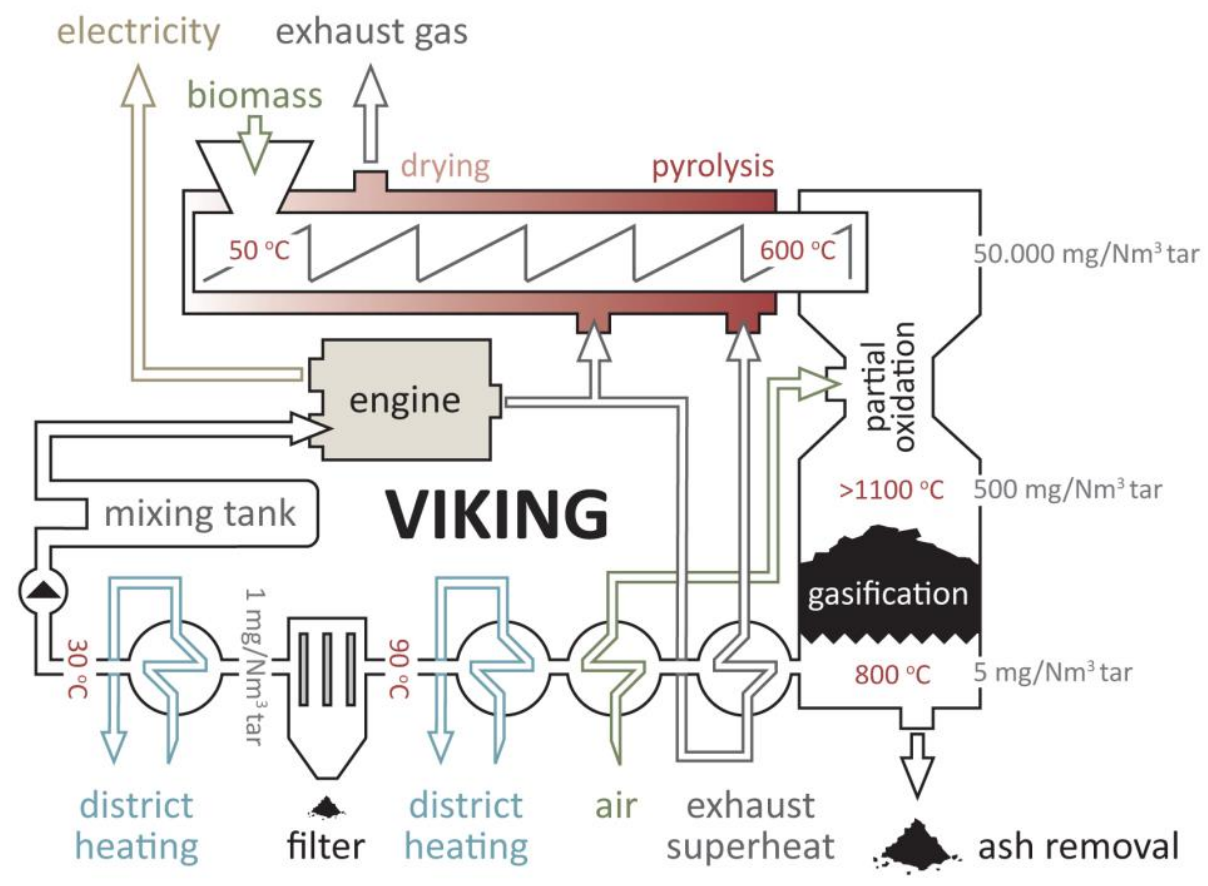

Figure 4: Process flow sheet for The Viking demonstration and research plant [11]

The plant was commissioned in the autumn of 2002 and has been operated for more than 4000 hours (3500 hours with engine operation). The main data of the plant are given in Table 3.

Table 3: Data from the Viking plant [11]

\begin{tabular}{|r|l|}
\hline Gasification concepts & TwoStage down draft \\
\hline Thermal input [kW] & 70 \\
\hline Feedstock [-] & Wood chips \\
\hline Electric output [kW] & 17.5 \\
\hline
\end{tabular}


To test the flexibility of the Viking gasifier, the BGG have simulated demand curves for consumption of both electricity and heat and fed these curves to the regulation of the plant. The district heating curve was based on empirical consumption data and the electricity curve was based on tariffs in 3 levels during a 24 hour cycle [12].

The demand- and production curves from the flexibility trials are showed in Figure 5 below, and the results proved that the Viking gasifier was capable of following fluctuations from $\sim 70$ $100 \%$ in the demand for electricity as well as for district heating. The production of heat following demand was interrupted twice due to unexplained pressure drop across the char bed. However, this does not influence the overall conclusion of the trials that the Viking gasifier seems a very suitable conversion process for production of CHP for fluctuating demands.

The conclusion of the trials was based on a series of investigations including gas quality measurements and forward temperature in the district heating water supply. The gas quality analysis from the trials is showed in Figure 6, and it was concluded that the stability of the gas was satisfactory throughout the trials, and that the minor variations do not influence the performance and efficiency of gasifier nor engine.
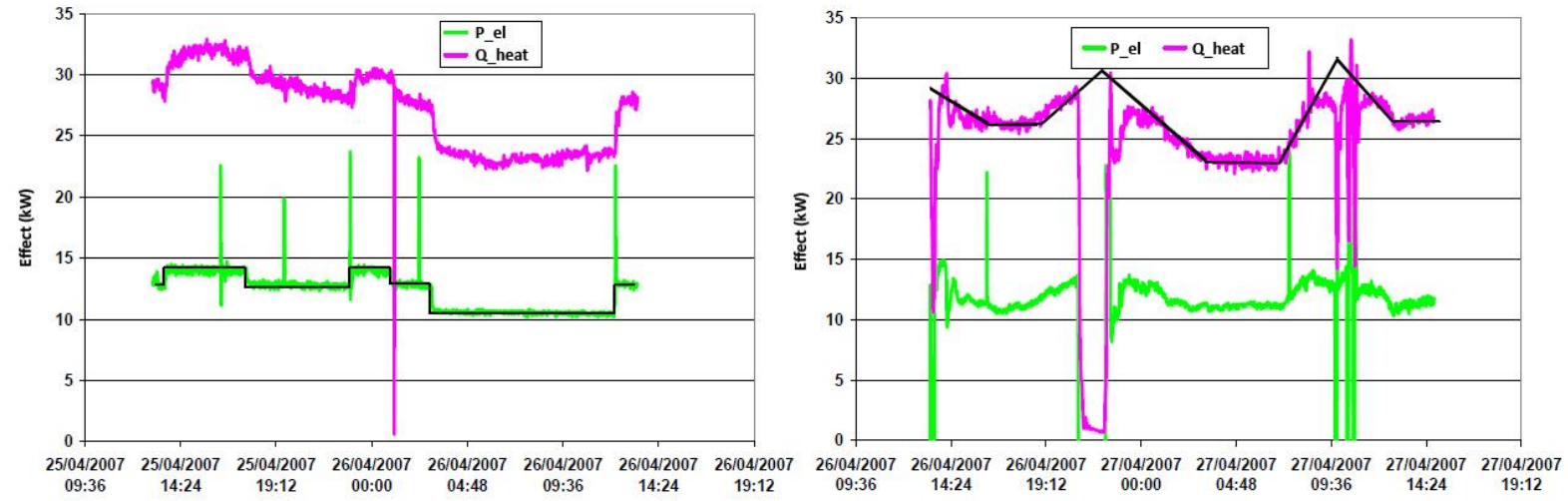

Figure 5: CHP production for fluctuating demand [12]
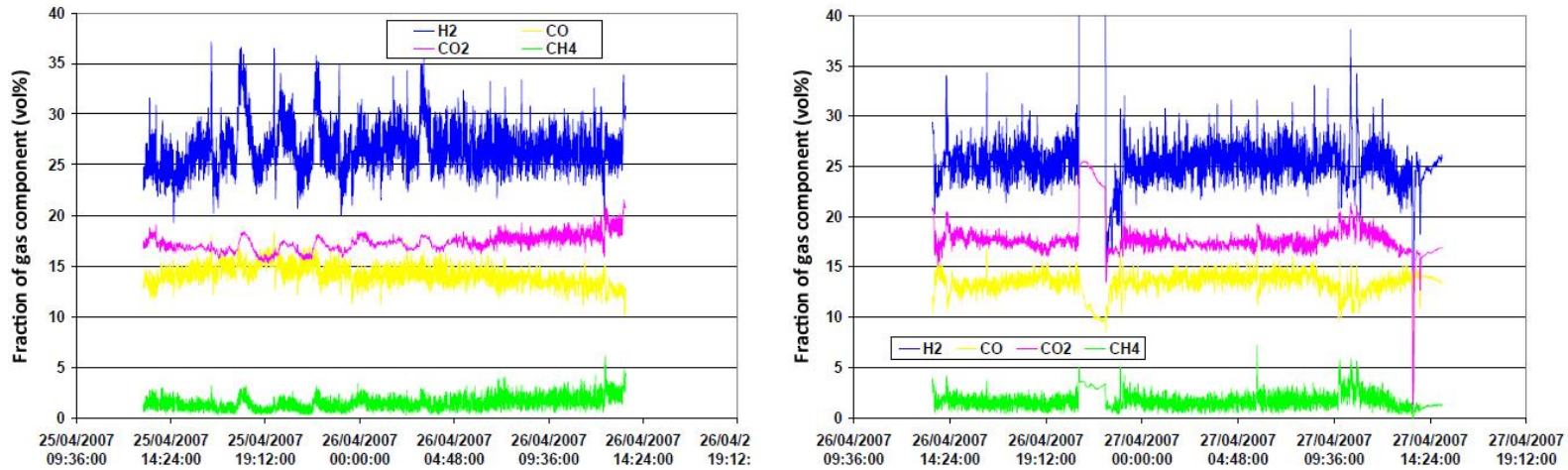

Figure 6: Gas composition during CHP production for fluctuating demand [12] 
To meet quality demands in district heating, it is important that the forward temperature of the water supply is constant. That this is the case in the flexibility trials is evident from the quality control curves in Figure 7. Production of district heating follows the demand curve, with changes in flow and a constant forward temperature.

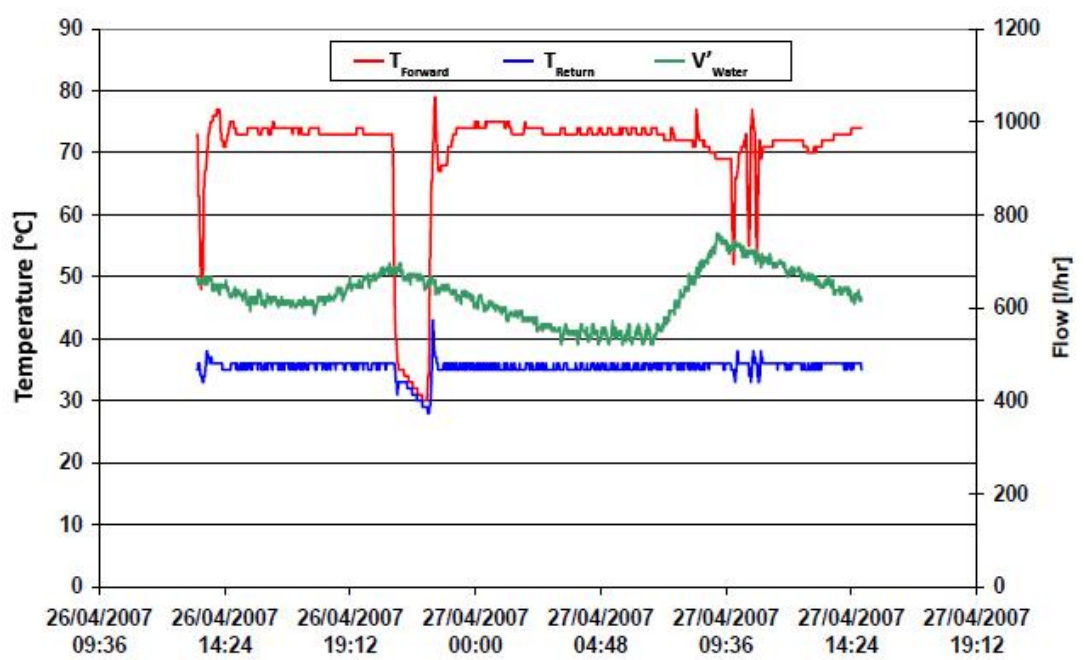

Figure 7: Forward temperature in district heating water [12]

The TwoStage concept of the Viking gasifier has been successfully upscaled to a $200 \mathrm{kWe}$ facility in Hadsund. Plant flow sheet is enclosed as Figure 8. Based on the first successful upscaling, work is now progressing rapidly in a second step, upscaling the platform to a 500 $\mathrm{kWe}$ plant. This plant will be situated in Hillerød and connected to the electricity grid and the municipal district heating grid for commercial cogeneration of electricity and district heating.

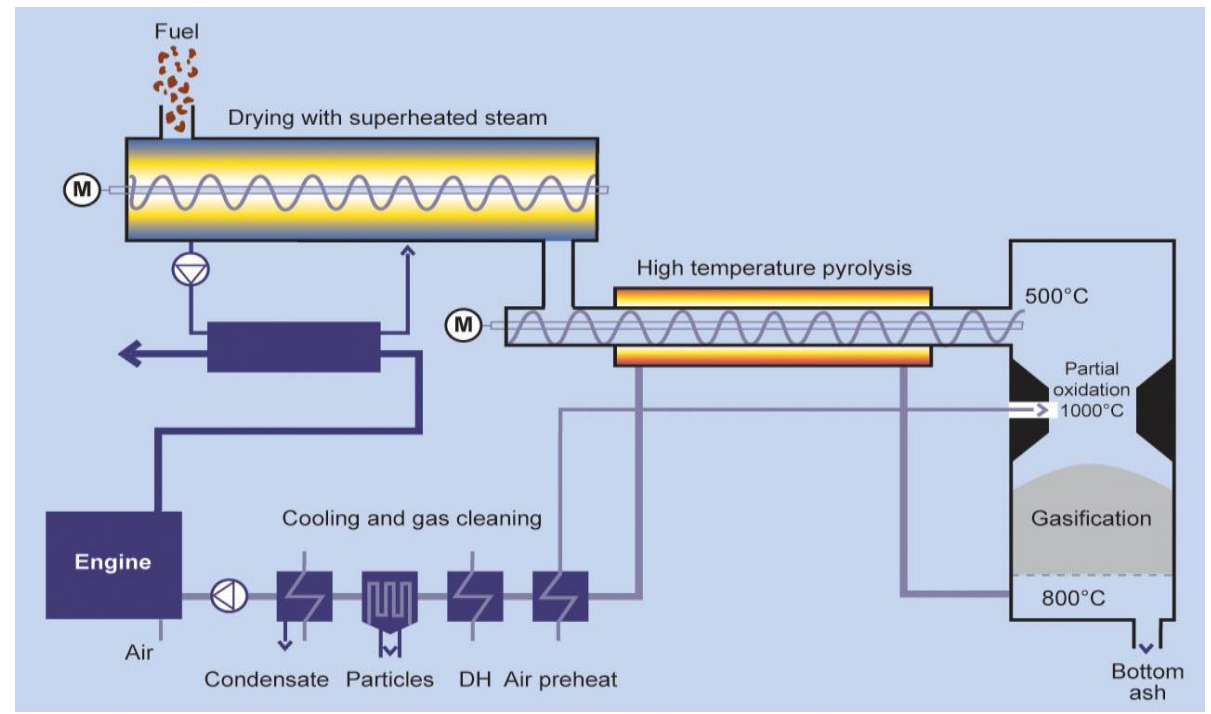

Figure 8: Process flow sheet for Weiss TwoStage gasification plant [13]

\subsection{Use of Solid Oxide Fuel Cells in CHP operation of a TwoStage downdraft biomass gasifier}

The gas engine is the primary bottleneck in achieving high electrical efficiency in small scale biomass gasifier systems. One of the novel approaches to overcome this problem, and increase the electricity output from the process is replacing the gas engine with a fuel cell stack. This change in the process implies very high quality demands to the producer gas, as fuel cells are 
usually very sensitive to impurities (catalyst inhibition, clogging, etc.) and many gasifiers do not provide gas of sufficiently high quality. The TwoStage downdraft gasifier Viking produces a very clean gas with high concentrations of $\mathrm{H}_{2}$ and $\mathrm{CO}$ and smaller amounts of $\mathrm{CH}_{4} \mathrm{H}_{2}$ as well as CO can be directly electrochemically converted in a Solid Oxide Fuel Cell, and if the level of impurities in the gas is sufficiently low it could potentially present a very robust platform for production of electricity from biomass. In addition to the direct conversion of $\mathrm{H}_{2}$ and $\mathrm{CO}$, the high temperatures used in SOFC systems in combination with nickel catalysts can also internally reform the fraction of $\mathrm{CH}_{4}$. The combination of high gas quality and good composition in the Viking producer gas yields a promising potential for use in Solid Oxide Fuel Cell (SOFC) systems $[14,15]$. This potential has already been strengthened by Hoffmann et al who operated a SOFC single cell on cleaned gas from the Viking gasifier for 150 hours without degrading the cell catalysts [15].

Based on the apparent potential of utilising SOFC in TwoStage biomass gasification, an extensive model based examination has been carried out. The study compares three different pathways to use process gas from the Viking gasifier in CHP production. Path 1 is conversion of the gas in a Micro Gas Turbine (MGT), path 2 is conversion in a SOFC, and path 3 applies a SOFC followed by subsequent conversion of residual energy content in a MGT. The study was based on steady-state process modelling through the use of a Dynamic Network Analysis tool (DNA). In addition, a component model of the SOFC was developed which included an electrochemical model and predicted effects of the operating temperature and pressure as well as the gas composition, fuel utilisation and load (current density), when predicting the SOFC performance [16]. The CHP setup evaluated in the SOFC $\rangle\langle\mathrm{MGT}\rangle\langle$ SOFC/MGT study is based on an up-scaled Viking gasifier model with $500 \mathrm{~kW}_{\text {thermal }}$ input. The gasifier model is simplified slightly compared to the Weiss TwoStage flow sheet presented in previous chapters, but aimed at providing good correlation with empirical data from this plant. The entire process including all units for use in the Gasifier-MGT, Gasifier-SOFC and Gasifier-SOFC-MGT configurations is depicted in Figure 9.

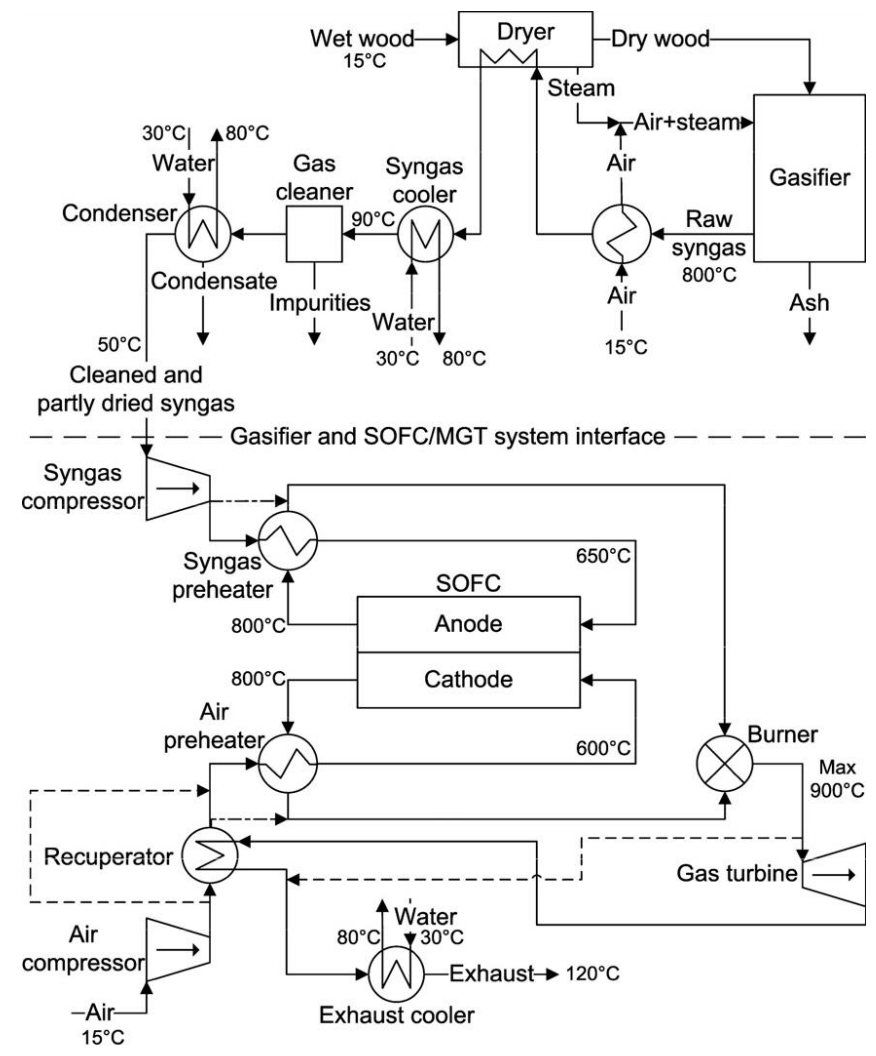

Figure 9: Flow sheet of simplified Viking gasifier with SOFC and/or MGT [15] 
Key data and main results for conversion process 1-3 is given in Table 4 below.

Table 4: Main results from SOFC $><$ MGT $><$ SOFC/MGT study [16]

\begin{tabular}{|r|l|l|l|}
\hline & Gasifier-MGT & Gasifier-SOFC & Gasifier-SOFC-MGT \\
\hline Biomass input [kW ${ }_{\text {th }}$ (LHV) & 499.2 & 499.2 & 499.2 \\
\hline Net power production [kW $\left.\mathrm{kW}_{\mathrm{el}}\right]$ & 140.1 & 181.5 & 251.0 \\
\hline District heating production [kW $\left.{ }_{\text {heat }}\right]$ & 239.7 & 216.6 & 146.7 \\
\hline$\eta_{\mathrm{el}}[\%](\mathrm{LHV})$ & 28.1 & 36.4 & 50.3 \\
\hline$\eta_{\mathrm{CHP}}[\%](\mathrm{LHV})$ & 76.1 & 79.7 & 79.7 \\
\hline
\end{tabular}

The results in Table 4 show a clear indication of the potential gain from successful integration of SOFC in CHP production via TwoStage downdraft gasification of biomass. From spring 2011 a project will be launched at Ris $\varnothing$ DTU in Denmark where the Biomass Gasification Group will conduct long term operation of a $2 \mathrm{~kW}$ SOFC stack fuelled with gas from the Viking gasifier. The project will be carried out in collaboration with the fuel cell department at Ris $\varnothing$ DTU, the department of mechanical engineering at DTU and Topsoe Fuel cells.

\section{Cogeneration of bio-fuels and electricity through biomass gasification}

Large vehicles like buses, trucks, tractors, ships and planes are highly unlikely to run on batteries any time soon, leaving fuel from biomass as the most feasible renewable alternative. Many types of bio-fuel exist today including green methane, bio-ethanol, Fischer-Tropsch Diesel, DME (Dimethyl ether), bio-oil, methanol, buthanol, Bio-SNG (Synthetic Natural Gas) etc. and the production processes differ as much as the product characteristics. In the following is given two examples on how to co-generate bio-fuels with electricity or district heating via thermal gasification of biomass. The processes described are cogeneration of district heating and bio-SNG in a FICFB in Güssing and cogeneration of electricity, district heating and methanol or DME in the Viking Twostage gasifier.

\subsection{Cogeneration of bio-fuels and district heating via FICFB gasification of biomass}

Construction of a large Fast Internal Circulating Fluidised Bed gasifier has been initiated in Gothenburg, Sweden, with the aim to turn wood waste (tree tops, roots and branches) into 1 TWh bio-SNG (biologically derived synthetic natural gas) per year in 2020. The plant is called GoBiGas and it is projected as a $100 \mathrm{MW}_{\mathrm{SNG}}$ twin-bed FICFB facility with first stage of the project being a $20 \mathrm{MW}_{\mathrm{SNG}}$ facility operating in 2012 , and then another $80 \mathrm{MW}_{\mathrm{SNG}}$ facility operating in 2016. The company behind GoBiGas - Göteborg Energi, owns a $1000 \mathrm{~km}$ long, district heating grid that can supply $90 \%$ of all homes in Gothenburg with heat and hot water. In combination with the daughter company Göteborg Energi Gas AB, who owns and controls a natural gas grid in the city, the infrastructure for utilization of the produced SNG is well suited for the task. The $1 \mathrm{TWh}$ of SNG from the GoBiGas plant could replace $30 \%$ of the current natural gas consumption, or fuel almost 75.000 Natural Gas Vehicles (NGVs). The goal is to reach $65 \%$ biomass-to-SNG efficiency, and overall energy efficiency above $90 \%$, including production of district heating [17].

Göteborg Energi who governs the GoBiGas project, had done intensive studies of indirect gasification and pressurized oxygen blown gasification, before selecting the twin-bed FICFB platform. Studies of FICFB gasification was based on the plant in Güssing, Austria described earlier. The Güssing gasifier has been equipped with and a Process Development Unit (PDU) of $1 \mathrm{MW}_{\mathrm{SNG}}$ capacity for cogeneration of bio-SNG and district heating. The PDU allows for demonstration of the complete bio-SNG production process including gasification, gas cleaning, methanation and gas upgrade. The first bio-SNG was produced by the PDU in April 
2009 , and in June the same year the production reached $1 \mathrm{MW}_{\mathrm{SNG}}$ equal to $100 \mathrm{~m}^{3} / \mathrm{h} \mathrm{SNG}$ in Hgas $^{1}$ quality [18]. The PDU process schematics are supplied in Figure 10.

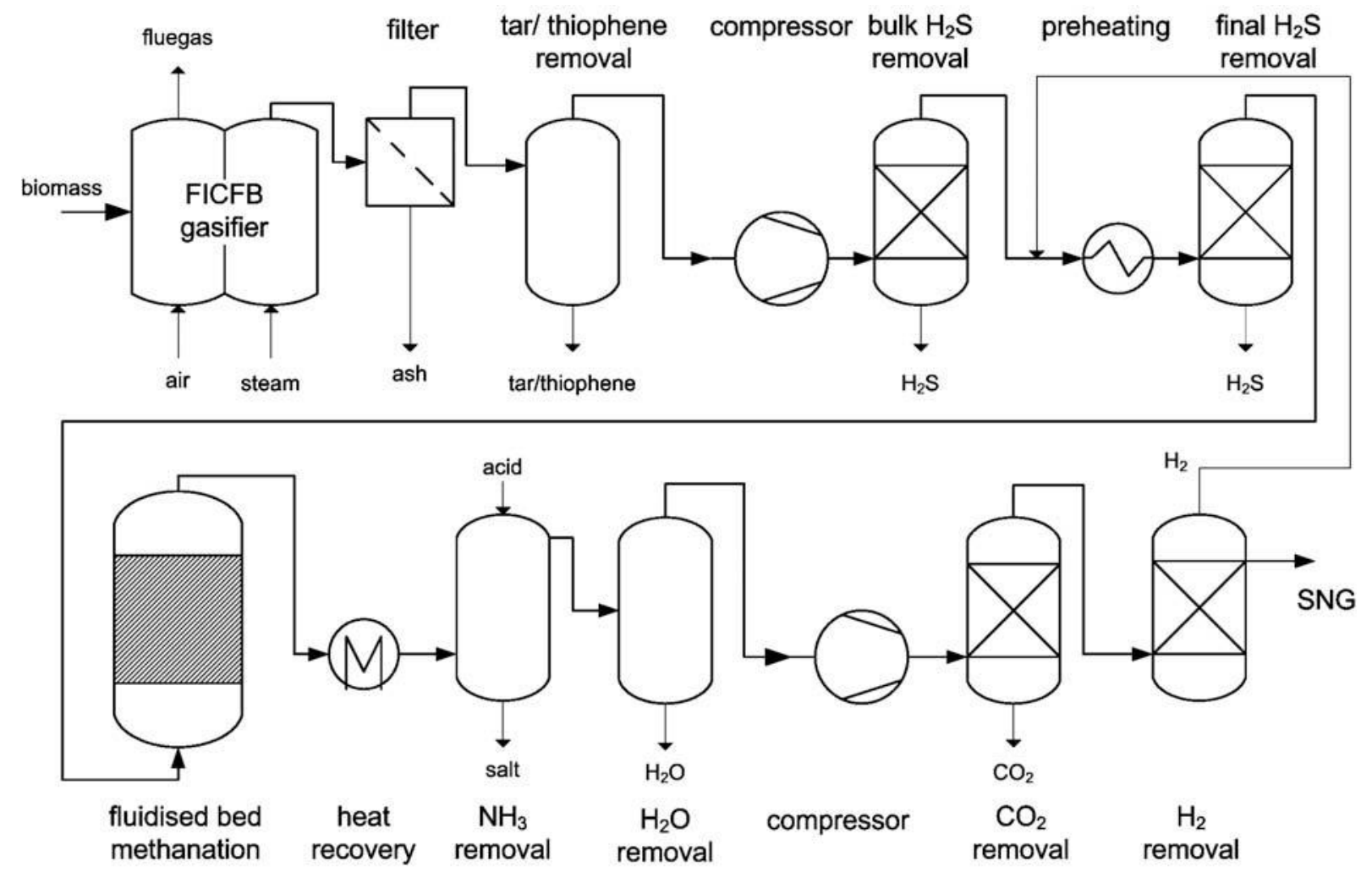

Figure 10: Schematics of the $1 \mathrm{MW}_{\text {SNG }}$ process development unit (PDU) in Güssing [18]

The twin-bed reactor in the FICFB PDU consists of a bubbling fluidized bed as gasifier and a circulating fluidized bed with a temperature around $850{ }^{\circ} \mathrm{C}$ in the gasification zone as combustor [19]. This combination has been identified as the most efficient combination of fluidized beds in a twin-bed construction [20]. The gas cleaning consists of a filter and a scrubber to remove dust and tars and undisclosed units to remove sulfur components, heavy hydrocarbons and aromatic compounds. Methanation takes place in an isothermal fluidized bed methanation technology system [18]. Finally, $\mathrm{CO}_{2}, \mathrm{H}_{2}, \mathrm{NH}_{4}$ and water are removed/recirculated before the gas is applicable to the natural gas grid [19]. Key process characteristics are given in Table 5.

Table 5: Key characteristics for bio-SNG production in Güssing FICFB [7, 21]

\begin{tabular}{|r|l|}
\hline SNG-process characteristics & FICFB PDU gasification \\
\hline Cold gas efficiency (\%) & $55-65$ \\
\hline Biomass-to-SNG efficiency (\%) & 54 \\
\hline Overall process efficiency (\%) & 97 \\
\hline - including production of district heating & \\
\hline Gas yield ( $\mathrm{Nm}^{3} / \mathrm{kg}$ biomass) & 1 \\
\hline
\end{tabular}

The production of bio-SNG via FICBF gasification of biomass is made more flexible if it includes the possibility to lead some of the gas to a gas engine or small gas turbine for production of electricity and heat instead of through the PDU.

${ }^{1}$ Wobbe index $14.0 \mathrm{MJ} / \mathrm{m}_{\mathrm{n}}^{3}$ and Higher Heating Value $=10.67 \mathrm{kWh} / \mathrm{Nm}^{3}$ 


\subsection{Production of methanol via TwoStage gasification}

Another relevant example on production of bio-fuels via cogeneration is the tri-generation of methanol or DME, electricity and district heating from wood chips via the small-scale TwoStage gasification process. These plants are highly efficient and the process gas is characterized by very low tar content and relatively high contents of $\mathrm{CO}$ and $\mathrm{H}_{2}$. Both traits are advantageous in relation to the gas cleaning systems and the synthesis of methanol or DME in subsequent catalytic processes. The technological processes of producing methanol or DME from biomass have been comprehensively studied, and the processes are very well reported in the literature (e.g., [22, 23, 24, 25]).

In 2010, Clausen et al. examined the overall efficiencies from tri-generation of methanol/DME with electricity and heat in the TwoStage gasifier positioned modelled as an upscaled version of the Viking gasifier with an input of $5 \mathrm{MW}_{\text {thermal }}$. The tri-generation process was designed as a once-through liquid fuel production and subsequent conversion of unused gas in a gas engine. The work implied results produced via DNA and Aspen in a model setup build from the simplified flow sheet illustrated in Figure 11 [26].

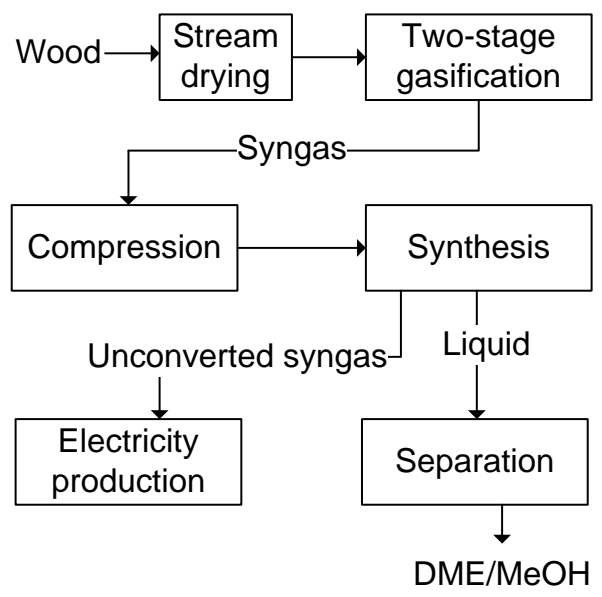

Figure 11: Simplified flow sheet of a small scale tri-generation of liquid fuel, electricity and heat from gasification of wood chips [26]

Models of both once-through plants (OT plants) and Recycling plants (RC plants) have been built, making it convenient to evaluate efficiency differences when maximizing the output of the liquid fuel. In the RC plants, about 76-79\% of the unconverted gas leaving the synthesis reactors is recycled back to the reactor, and the remaining $21-24 \%$ is used for power production. The main results of the work is given in Figure 12, where the four different plant designs (methanol $><\mathrm{DME}$ and $\mathrm{OT}>\mathrm{RC}$ ) are compared to each other and to two large scale DME processes from literature [27]. 


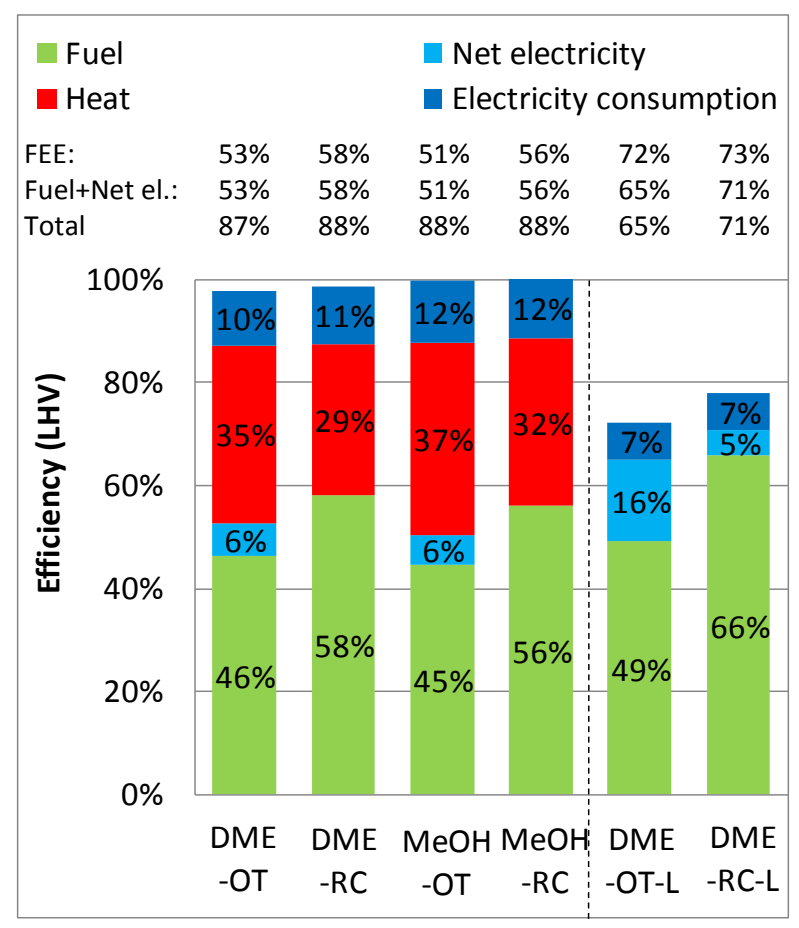

Figure 12: Efficiency calculations of tri-generation of liquid fuel, electricity and district heating in a $5 \mathrm{MW}_{\mathrm{TH}}$ TwoStage downdraft gasifier [26].

If the performances of the DME/methanol plants are compared between OT plants and RC plants respectively, and with DME calculated as methanol-equivalents, it is difficult to conclude that one type is better than the other. However, the design of the DME plant is slightly more complex and therefore a methanol plant may be more suited for small-scale production. The calculated energy efficiencies from biomass to methanol/DME and electricity are 51-53\% (LHV) for the OT-process, and 56-58\% (LHV) for RC-process. If the district heating is added as product to the efficiency calculations, then the total energy efficiency of the plants is increased to $87-88 \%$ (LHV).

As indicated in Figure 12, a 6-8\% higher fuel and electricity efficiency can be expected in a larger DME plant. The study showed that the main reason for this difference between the small and large scale DME production was the use of air-blown gasification at atmospheric pressure in the small-scale plants. This results in high compressor duties before fuel synthesis and high inert content in the synthesis reactor [26]. The efficiency gap between the small and large scale production might be set of from the inclusion of transportation requirements, utility of the produced district heating and flexibility benefits. In this case the optimal position and scale of the plants and the overall process efficiency would be highly situation specific.

\section{Cogeneration of heat, power (and fertilizer) in LT-CFB gasification}

The gasification platforms discussed so far have all been limited to the use of slow growing biomass with low ash content - wood. However, the biomass resource is scarce and highly diverse, and therefore technologies utilising a broad variety of biomass types in energy production are desirable. The Low Temperature Circulating Fluid Bed (LT-CFB) gasifier is such a platform.

The LT-CFB - alias the Pyroneer [28], has been designed specifically to gasify biomass resources with high contents of low melting ash compounds that has proven difficult to convert in other processes - e.g. straw, manure fibres, sewage sludge, organic waste etc. The process is based on separate pyrolysis and gasification reactors with a suitable heating medium circulating 
to transfer heat from the gasification process to the pyrolysis. The temperature is kept below the melting point of the ash components - i.e. max process temperatures around $700-750{ }^{\circ} \mathrm{C}$. In this way sintering of the ash and subsequent fouling (from e.g. potassium) or corrosion (from e.g. chlorine) of the plant unit operations are avoided as these compounds will leave the process in solid form, deposited on ash particles [29]. The plant flow sheet is illustrated in Figure 13.

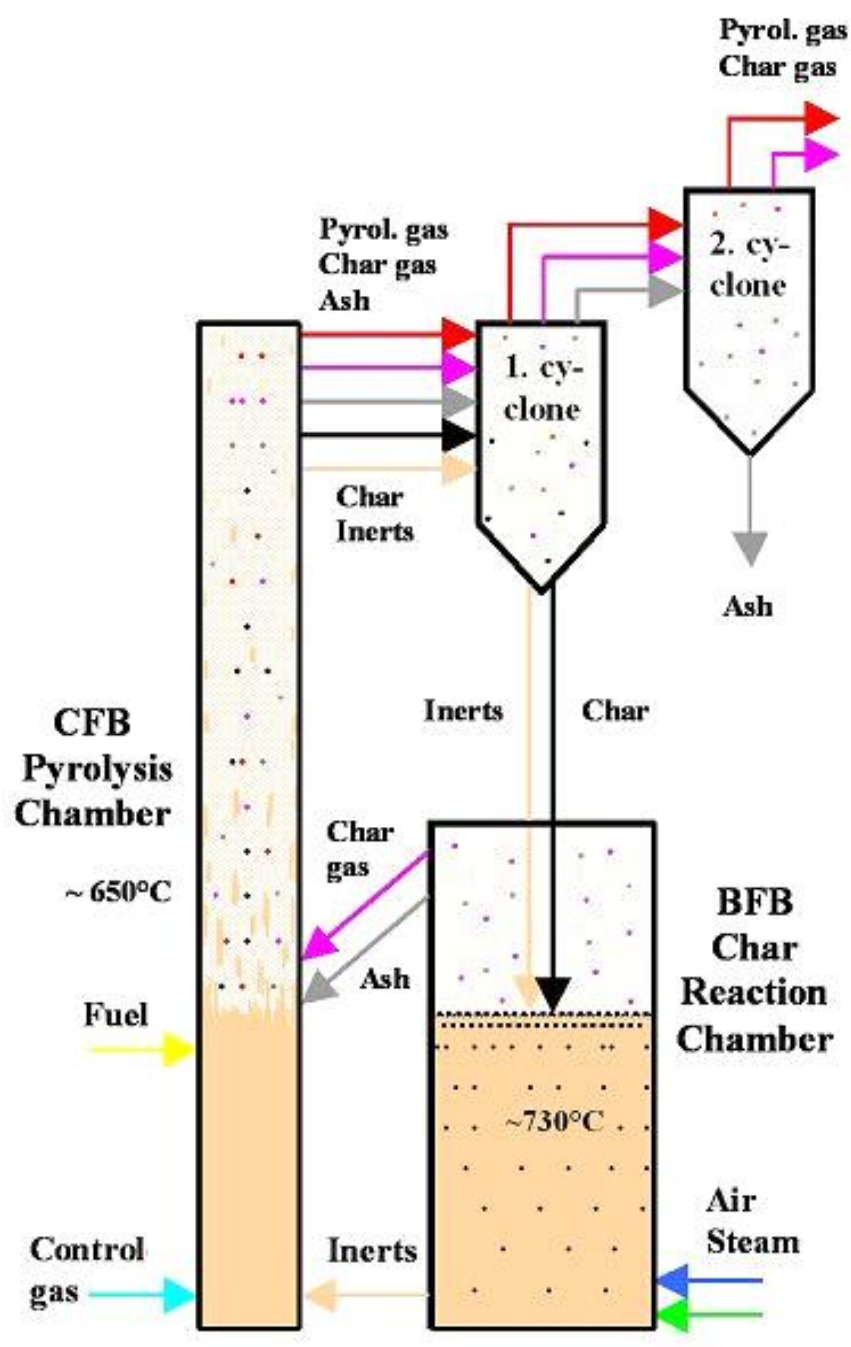

Figure 13: Flow sheet of the LT-CFB gasifier [29]

In a $500 \mathrm{~kW}_{\text {thermal }}$ unit at the Technical University of Denmark, cold gas efficiencies of 87-93\% was achieved on various feed stocks, and based on these results it is expected that the efficiency of the plant can reach $>95 \%$ on a larger scale [29].

A drawback of the LT-CFB process is that the produced gas has a very high content of tar particles, rendering it unsuitable for synthesis processes, as well as fuel cell and gas engine operation. In its present form, the LT-CFB is therefore used in cooperation with large power plants, where the gas from the LT-CFB is co-fired with e.g. coal. In Denmark such a system has been constructed by DONG in Kalundborg where a $6 \mathrm{MW}_{\text {thermal }}$ LT-CFB will be gasifying straw and supply the process gas to Unit 2 of the 1000 MW coal fired power plant Asnæsværket. If successful operation on straw is achieved other difficult types of biomass will be tested. Operation will begin in March 2011, the project will finish in 2013, and if successful it will be succeeded by a full scale plant [30].

The LT-CFB is a highly scalable concept, with potential plant sizes of 5-100 MW depending on the fuel. Desired fuel characteristics include small particle size (3-4 $\mathrm{mm})$ and limited water content $(<30 \mathrm{wt} \%)$. Successful operation on two different types of straw, chicken manure, two 
types of pig manure, two types of degassed manure from biogas plants and one type of wood have been carried out on a small scale LT-CFB at the Technical University of Denmark. These fuels had ash content as high as $44 \mathrm{wt} \%_{\text {dry }}$ and a high content of potassium, chlorine and phosphorous [29].

To increase the future usability of the LT-CFB process gas, a new project has recently been initiated at the Biomass Gasification Group at Risø DTU in Denmark. The aim is to develop new gas cleaning and upgrading techniques that will reduce the content of tar and dust particles in the gas, and make it usable for synthesis or direct production of electricity.

\subsection{Fertilizer from ash and residual carbon as gasification product}

In addition to the utilization of troublesome marginal biomass resources, the LT-CFB design has a series of additional selling propositions. These include low construction and maintenance costs due to simple and robust design, high scalability and avoidance of toxic PAH compounds (poly aromatic hydrocarbons) in the solid residual fraction [29].

The prospect that the low operation temperature in the LT-CFB process prevents PAH production opens up for potential uses of the ash fraction that would otherwise be prohibited. Recirculation of organic carbon and nutrients - especially phosphorus, would significantly increase the long term sustainability of the process and could also improve any Life Cycle Assessment of the facility as well the overall process carbon-balance.

Some very important issues regarding the use of LT-CFB ash as fertilizer have been addressed recently for ash from pig manure [31]. Results showed that the LT-CFB ash contained high total content of calcium (40\%), iron (3-5\%), phosphorus (3-6\%), potassium (1-3.5\%), sulfur (1.5-2\%) and magnesium (0.3-2\%) and minor amounts of heavy metals, such as zinc (1000$3400 \mathrm{mg} / \mathrm{kg}$ ), copper (200-470 mg/kg), chromium $(60-250 \mathrm{mg} / \mathrm{kg})$ and nickel $(20-110 \mathrm{mg} / \mathrm{kg})$. In field trials the plant availability of the phosphorus in the ash was initially lower than from soluble fertilizer, but it increased significantly over time. It was also shown that the leaching of the nutrients was equally lower from the ash than from the commercial fertilizer and all in all the total uptake of phosphorus from the ash was similar to the uptake of phosphorous from mineral fertilizer $\left(\mathrm{Na}_{2} \mathrm{HPO}_{4}\right.$ aka DSP - disodium phosphate). However, the initial delay inhibited plant growth on the species tested. Therefore, the study showed no significant improvement in barley yield from the application of LT-CFB manure ash on agricultural soil compared to no treatment despite a large plant uptake of phosphorus from the ash. The study also showed that the immediate availability of the ash phosphorous could be increased using acid extraction subsequently neutralized to $\mathrm{pH}$ 7. In this way as lime was removed from the ash prior to use and the uptake rate of phosphorous from the ash was increased with a factor 3 . The acid treatment gave the ash extract an agronomic effectiveness as good as that for disodium phosphate. For ryegrass grown on Australian acidic soil, the use of LT-CFB ash as fertilizer gave yields similar to those grown with the use of monocalcium phosphate. All in all the ash was showed to elevate soil $\mathrm{pH}$ (from 4.5 to 7.9 and thus eliminating various plant toxicities), increase soil Olsen $\mathrm{P}$ and increase water holding capacity, and it was the conclusion of the study that "In general the results indicate that the nutrients in pig manure gasifier ash can be safely recycled in the agricultural ecosystem, providing added value to this method of renewable energy production" [31].

In addition to the recycling of valuable nutrients, the use of ash from the LT-CFB as fertilizer could also be used as a way to increase the level of organic carbon in the farm soil. If a fraction of char is left un-gasified in the solid residuals and these are amended to farm soil, then this char would obtain character of biochar with the concomitant benefits. Biochar is defined as char amended to soil for the purpose of soil enhancement and climate change mitigation. Research in this field is still in its youth, but studies suggest that there is a series of benefits connected to the application of biochar. Like active charcoal, biochar has the ability to adsorb 
various ions and compounds. This could prevent valuable nutrients from being washed from soil layers into the ground water, as well as it could help to reduce emissions of $\mathrm{CH}_{4}$ and $\mathrm{N}_{2} \mathrm{O}$ from the soil [32]. Furthermore, biochar in sandy soils is known to positively influence water holding capacity and soil structure and architecture [33, 34, 35].

Leaving a fraction of char unconverted in this way will reduce the overall energy efficency of the LT-CFB process, but at the same time it could aid in the regeneration of depleted soils and increase sustainability of the process. Another benefit from amending char to farm soil is the contribution from the recalcitrant nature of the char in the construction of a carbon sink, and thereby a positive impact on the process carbon balance. With this process change, electricity and heat from LT-CFB gasification of biomass could be classified as genuine carbon-neutral energy. This genuity should be regarded in contrast to the present consensus where most "carbon neutral" energy sources have positive carbon balances - e.g. 50-150 kg CO 2 emitted per ton wheat straw incinerated in a series of Danish energy scenarios [36].

\section{Overview and comparison of assessed gasification platforms}

For the purpose of overview the different approaches to cogeneration via gasification included in this article are collected in the table below:

Table 6: Overview of reviewed cogeneration platforms for biomass gasification.

Green: Theoretical values, Purple: Model results, Yellow: Process aims.

\begin{tabular}{|c|c|c|c|c|c|c|c|}
\hline $\begin{array}{l}\text { Gasification } \\
\text { platform }\end{array}$ & $\begin{array}{l}\text { Platform ad- } \\
\text { on }\end{array}$ & $\begin{array}{l}\text { Input } \\
\left(\mathrm{MW}_{\mathrm{th}}\right)\end{array}$ & $\begin{array}{l}\eta_{\text {electrical }} \\
(\%)\end{array}$ & $\begin{array}{l}\eta_{\text {thermal }} \\
(\%)\end{array}$ & $\begin{array}{l}\eta_{\text {biofuel }} \\
(\%)\end{array}$ & $\begin{array}{l}\eta_{\text {total }} \\
(\%)\end{array}$ & Misc. \\
\hline Updraft & Gas engine & 5.2 & 28 & 55 & - & 83 & \\
\hline FICFB & Gas engine & 8 & 25 & 56 & - & 81 & \\
\hline FICFB & $\mathrm{PDU}_{\mathrm{SNG}}$ & 8 & & 43 & 54 & 97 & Gaseous fuel \\
\hline TwoStage $_{\text {Hillerød }}$ & Gas engine & 1.5 & 35 & 55 & - & 90 & \\
\hline TwoStage $_{\text {Viking }}$ & Gas engine & 0.07 & 25 & 46 & - & 71 & Small scale \\
\hline TwoStage $_{\text {Model }}$ & $\mathrm{SOFC}+\mathrm{MGT}$ & 0.5 & 50 & 30 & - & 80 & High temp. Heat \\
\hline TwoStage $_{\text {Model }}$ & OT unit ${ }_{\mathrm{MeOH}}$ & 5 & 6 & 45 & 37 & 88 & Liquid fuel \\
\hline TwoStage $_{\text {Model }}$ & RC unit ${ }_{D M E}$ & 5 & - & 29 & 58 & 87 & Liquid fuel \\
\hline LT-CFB & $\begin{array}{l}\text { Power plant } \\
\text { steam cycle }\end{array}$ & $\begin{array}{l}6 \text { (of } 368 \\
\text { total) }\end{array}$ & 38 & 52 & - & 90 & $\begin{array}{l}\text { Fertilizer } \\
\text { production }\end{array}$ \\
\hline
\end{tabular}

\section{Conclusions}

A series of different gasification process designs have been presented to give insight to the wide range of possibilities within this category. Focus in the review has been on state-of-the-art processes with high reliability, flexibility and efficiency within cogeneration of energy commodities from conversion of biomass. Despite the small selection of platforms included in the study, it is evident that there are many ways to utilise gasification of biomass for cogeneration. The optimal choice of technology for a given task will depend on many factors including feed stock availability, knowhow, project economy, local politics, environmental concerns and LCA considerations in addition to the desired product and process characteristics and demands. 


\section{References}

[1] The Danish Energy Agency's map of energy streams (in Danish):

http://www.ens.dk/da-DK/Info/TalOgKort/Statistik_og_noegletal/Aarsstatistik/Documents/Energistr\%C3\%B8m\%202009.pdf

[2] The Danish Energy Agency's interactive energy maps:

http://www.ens.dk/en-US/Info/FactsAndFigures/EnergyInfoMaps/InteractiveMaps/Sider/Forside.aspx

[3] The figure and this section are from "Success stories, Harboøre plant".

The section of the Harboøre gasifier is also based on: Babcock \& Wilcox Vølund gasifier based

Combined Heat \& Power, Dr. Bjørn Teislev, Manager, BWV R\&D.

[4] Heeb, Robert, 2010, "B\&W Vølund - Up-date on the Harboøre Technology", power point presentation given at course on thermal gasification of biomass at The Danish Society of Engineers (IDA), Copenhagen, Denmark, $10^{\text {th }}$ of May 2010. Presentation available at: http://ida.dk/netvaerk/idaforum/U0637a/Documents/Termisk\%20Forgasning\%20den\%2019.\%20maj\%202010/VoelundRobert\%20Heeb-may\%2019\%20gasification.pdf

[5] Biomass CHP Plant Güssing - A Success Story, Hofbauer Hermann, Rauch Reinhard, Bosch Klaus, Koch Reinhard, Aichernig Christian.

[6] Rauch, R., 2005, "Indirectly heated gasifiers - the case of the Güssing reactor", $1^{\text {st }}$ European Summer School on Renewable Motor Fuels, Birkenfeld, Germany. Report available: http://www.baumgroup.de/Renew/documents/10_R_Rauch\%5CR.Rauch\%20-\%20Indirectly\%20heated\%20gasifiers\%20$\% 20$ the $\% 20$ case $\% 20$ of $\% 20$ the $\% 20 \mathrm{G} \% \mathrm{C} 3 \%$ BCssing\%20reactor\%20-\%20paper.pdf

[7] Biollaz, S., 2009, “The SNG Technology Platform in Güssing, A Status report of Bio-SNG project”, Poster presented at European Biofuels Technology Platform: Second Stakeholder Plenary Meeting (SPM2), 22nd of January 2009, Brussels.

[8] Henriksen U., 2004, "Termisk forgasning af biomasse", Department of Mechanical Engineering, DTU, Ph.d. Thesis, MEK-ET-PHD-2004-01, 138 pages, ISBN 87-7475-321-5. In parts in Danish and English.

[9] Gøbel, B., Bentzen, J. D., Hindsgaul, C., Henriksen, U., Ahrenfeldt, J., Fock, F., Houbak, N., Qvale, B., 2002, "High Performance Gasification with the Two-Stage Gasifier", Proceedings of 12th European Conference and Technology Exhibition on Biomass for Energy, Industry and Climate Protection, pp. 389-395, June, 2002, Amsterdam, The Netherlands. [10] Henriksen, U., Ahrenfeldt, J., Jensen, T. K., Gøbel, B., Bentzen, J. B., Hindsgaul C., Sørensen, L. H., 2006, "The Design, Construction and Operation of a 75 kW Two-Stage Gasifier". Energy, Vol. 31, Issues 10-11, pp. 1542-1553.

[11] Henriksen, U., 2003, “The Viking Gasifier”, Power Point presentation, IEA-meeting, London, May 2003.

[12] Henriksen U., Ahrenfeldt, J., 2007, "Indpasning af totrinsforgasser i et energisystem (videregående undersøgelser af Viking - forgasseren)", PSO projekt FU4201, MEK, DTU, november 2007.

[13] Henriksen U., 2010, "Udvikling og opskalering af Totrinsforgasser til forgasning af Biomasse", power point presentation given at course on thermal gasification of biomass at The Danish Society of Engineers (IDA), Copenhagen, Denmark, $10^{\text {th }}$ of May 2010. Available at: http://ida.dk/netvaerk/idaforum/U0637a/Documents/Termisk\%20Forgasning\%20den\%2019.\%20maj\%202010/Ulrik\%20henrik sen\%20DTU\%20Ris\%C3\%B8\%20totrinsforgasseren.pdf

[14] Larmine, J., Dicks, A., "Fuel Cell Systems Explained - second edition", 2003, Wiley, West Sussex, England, ISBN-13: 978-0-470-84857-9 (H/B).

[15] Hofmann P, Schweiger A, Fryda L, Panopoulos KD, Hohenwarter U, Bentzen JD, et al., 2007, "High temperature electrolyte supported Ni-GDC/YSZ/LSM SOFC operation on two-stage Viking gasifier product gas". Power Sources, Vol. 173, pp 357-66.

[16] Bang-Møller C., Rokni M., 2010,'Thermodynamic performance study of biomass gasification, solid oxide fuel cell and micro gas turbine hybrid systems". Energy Conversion and Management, Vol. 51, pp 2330-2339.

[17] Göteborg Energi AB, 2009. Gothenburg Biomass Gasification Project, GoBiGas.

Göteborg Energi. [Online]

http://www.goteborgenergi.se/English_Projects_GoBiGas_Gothenburg_Biomass_Gasification_Project_DXNI9238273_.aspx. 
[18] Kopyscinski, J., Schildhauer, T. J. and Biollaz, S. M. A, 2010, "Production of synthetic natural gas (SNG) from coal and dry biomass - A technology review from 1950 to 2009”. Fuel, Vol. 89, pp 1763-1783.

[19] Rauch, R., 2009,” Bio-SNG - preliminary report”, Vienna University of Technology, Paul Scherrer Institute. Preliminary report for the 4th BTLtec 2009.

[20] Xu, G., et al, 2006, "The superior technical choice for a dual fluidized bed gasification". Ind. Eng. Chem. Res. Vol. 45, 2006.

[21] Bengtsson, K., 2007, "Twin-bed gasification concepts for Bio-SNG Production", Lund, Sweden : Department of Chemical Egineering, Lund University, 2007.

[22] Sues A, Juraščík M, Ptasinski K., 2010, "Exergetic evaluation of 5 biowastes-to-biofuels routes via gasification”, Energy, Vol. 35(2), pp 996-1007

[23] Hamelinck, C. N., Faaij, A. P. C, 2001, "Future prospects for production of methanol and hydrogen from biomass", report NWS-E-2001-49. Utrecht, The Netherlands: Utrecht University, Copernicus Institute, 2001. Available at:

http://www.mtholyoke.edu/courses/tmillett/course/geog_304B/e2001-49.pdf

[24] Larson, E. D., Jin, H., Celik, F.E., 2009, "Large-scale gasification-based coproduction of fuels and electricity from switchgrass". Biofuels, Biorprod. Bioref, Vol. 3, pp. 174-194.

[25] Pettersson, K., Harveya, S., 2010, "CO2 emission balances for different black liquor gasification biorefinery concepts for production of electricity or second-generation liquid biofuels", Energy, Vol. 35(2), pp. 1101-1106.

[26] Clausen, L. R., Elmegaard, B., Ahrenfeldt, J., Henriksen, U., 2011, "Thermodynamic analysis of small-scale DME and methanol plants based on the efficienct Two-stage gasifier", Submitted to Energy, 2011.

[27] Clausen, L. R., Elmegaard, B., Houbak, N., 2010, "Technoeconomic analysis of a low $\mathrm{CO} 2$ emission dimethyl ether (DME) plant based on gasification of torrefied biomass", Energy, Vol. 35 (12), pp 4831-4842.

[28] DONG Energy, 2011. News - From LT-CFB to Pyroneer. DONG Energy. [Online] http://www.dongenergy.com/pyroneer/News/news/Pages/FromLT-CFBtoPyroneer.aspx

[29] Nielsen, R. G., 2007,'Lav Temperatur Cirkulerende Fluid Bed forgasningsprocessen til biomasse med højt askeindhold”, phD thesis, Energy Engineering Section, Department of Mechanical Engineering, Technical University of Denmark, ISBN No.: 978-87-90130-15-2 [30] DONG Energy, 2010. LT-CFB technology, Demonstration plant. DONG Energy. [Online] http://www.dongenergy.com/LT-CFB/Demonstration_Plant/Pages/Asnaes_power_plant.aspx [31] Kuligowski, K., 2009, "Utilization of ash from thermal gasification of pig manure as pfertilizer and soil amendment", phD thesis, Department of Biotechnology, Chemistry and Environmental Engineering, Aalborg University, ISBN: 978-87-90033-68-2. Available at: http://vbn.aau.dk/files/33123554/PhD\%20thesis\%20Ksawery\%20Kuligowski.pdf

[32] Zwieten, L., et al. 2009, "Biochar and Emissions of Non-CO2 Greenhouse Gases from Soil", [book auth.] J. (ed.) Lehmann and S. (ed.) Joseph. Biochar for Environmental Management - Science and Technology. London: Earthscan, 2009.

[33] Laird, D., et al. 2009, "Impact of biochar amendments on soil quality for a typical midwestern agricultural soil", Poster presentation, North American Biochar Conference, 9-12 August 2009. Boulder, Colorado, USA: s.n., 2009.

[34] Lehmann, J. and Josph, S., 2009, "Biochar for Environmental Management: An Introduction", [book auth.] J. (ed.) Lehmann and S. (ed.) Joseph. Biochar for Environmental Management - Science and Technology. London : Earthscan, 2009, pp. 1-12.

[35] Thies, J. E. and Rillig, M. C., 2009, "Characteristics of Biochar: Biological Properties", [book auth.] J. Lehmann and S. Joseph. Biochar for Environmental Management - Science and Technology. London : Earthscan, 2009.

[36] Thomsen, T., Hauggaard-Nielsen, H., Bruun, E., Ahrenfeldt, J., 2011, “The potential of pyrolysis technology in climate change mitigation - influence of process design and parameters, simulated in SuperPro Designer Software”, Risø-R report 1764, ISSN: 0106-2840, ISBN: 978-87-550-3877-6. Available at:

http://orbit.dtu.dk/getResource?recordId=274130\&objectId=1\&versionId=1 